$$
\begin{gathered}
\text { U.S. Arruy Coast. Eug Res Ctr.PP } \\
\text { TP 79.1 }
\end{gathered}
$$

\title{
Relation Between Immersed Weight and Volume Rates of Longshore Transport
}
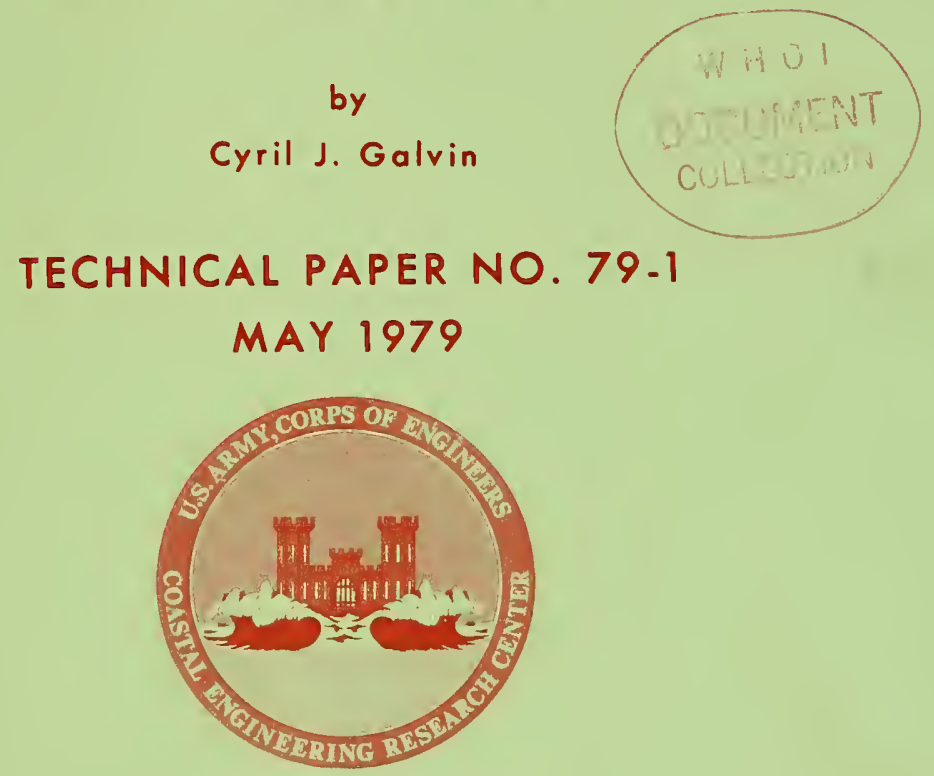

(1)

Approved for public release; distribution unlimited.

U.S. ARMY, CORPS OF ENGINEERS COASTAL ENGINEERING RESEARCH CENTER

Kingman Building

Fort Belvoir, Va. 22060 



$$
\begin{gathered}
\text { U.S. Armyg Coast. Eng Res. Etr.TP } \\
\text { TP 79-1 }
\end{gathered}
$$

\title{
Relation Between Immersed \\ Weight and Volume Rates of Longshore Transport
}

\author{
by \\ Cyril J. Galvin
}

TECHNICAL PAPER NO. 79-1

\section{MAY 1979}

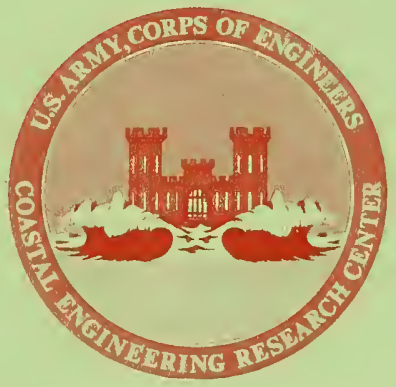

Approved for public release; distribution unlimited.

U.S. ARMY, CORPS OF ENGINEERS

COASTAL ENGINEERING

RESEARCH CENTER

Kingman Building

Fort Belvoir, Va. 22060 
Reprint or republication of any of this material shall give appropriate credit to the U.S. Army Coastal Engineering Research Center.

Limited free distribution within the United States of single copies of this publication has been made by this Center. Additional copies are available from:

\author{
National Technical Information Service \\ ATTN: Operations Division \\ 5285 Port Royal Road \\ Springfield, Virginia 22161
}

The findings in this report are not to be construed as an official Department of the Army position unless so designated by other authorized documents. 


\begin{tabular}{|c|c|}
\hline REPORT DOCUMENTATION PAGE & $\begin{array}{l}\text { READ INSTRUCTIONS } \\
\text { BEFORE COMPLETING FORM }\end{array}$ \\
\hline 2. GOVT ACCESSION NO. & 3. RECIPIENT'S CATALOG NUMBER \\
\hline $\begin{array}{l}\text { 4. TITLE (and Subttie) } \\
\text { RELATION BETWEEN IMMERSED WEIGHT AND VOLUME }\end{array}$ & $\begin{array}{l}\text { S. TYPE OF REPORT \& PERIOD COVERED } \\
\text { Technical Paper }\end{array}$ \\
\hline RATES OF LONGSHORE TRANSPORT & 6. PERFORMING ORG. REPORT NUMBER \\
\hline $\begin{array}{l}\text { 7. AuTHOR(o) } \\
\text { Cyril J. Galvin }\end{array}$ & 8. CONTRACT OR GRANT NUMBER(s) \\
\hline $\begin{array}{l}\text { 9. PERFORMING ORGANIZATION NAME AND ADDRESS } \\
\text { Department of the Army } \\
\text { Coastal Engineering Research Center (CERRE-CP) } \\
\text { Kingman Building, Fort Belvoir, Virginia } 22060\end{array}$ & $\begin{array}{l}\text { 10. PROGRAM ELEMENT, PROJECT, TASK } \\
\text { AREA \& WORK UNIT NUMBERS } \\
\text { D3 } 1196\end{array}$ \\
\hline $\begin{array}{l}\text { 11. CONTROLLING OFFICE NAME AND ADDRESS } \\
\text { Department of the Army }\end{array}$ & $\begin{array}{l}\text { 12. REPORT DATE } \\
\text { MaY } 1979\end{array}$ \\
\hline $\begin{array}{l}\text { Coastal Engineering Research Center } \\
\text { Kingman Building, Fort Belvoir, Virginia } 22060\end{array}$ & $\begin{array}{l}\text { 13. NUMBER OF PAGES } \\
15\end{array}$ \\
\hline 14. MONITORING AGENCY NAME \& AODRESS(If dlfferent Irom Controlling Offlca) & $\begin{array}{l}\text { 15. SECURITY CLASS. (of thlo roport) } \\
\text { UNCLASSIFIED }\end{array}$ \\
\hline & $\begin{array}{l}\text { 1Sa. OECLASSIFICATION/DOWNGRADING } \\
\text { SCHEOULE }\end{array}$ \\
\hline
\end{tabular}

Approved for public release; distribution unlimited.

17. DISTRIBUTION STATEMENT (of the abstract antared in Block 20, if different from Roport)

18. SUPPLEMENTARY NOTES

19. KEY WOROS (Continue on reveree alde if necossary end tdentify by block number)

Energy flux methods

Littoral material
Longshore transport

Sand

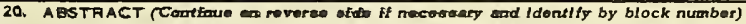

As presently used, the immersed weight rate, $\mathrm{I}_{\ell}$, is the volume rate, Q, of longshore transport, multiplied by a constant. For use in engineering problems, Il must be converted back to the equivalent $Q$. The $I_{\ell}$ formulation may be important where the unit weight of sand differs significantly from the unit weight of sand at the open-coast sites contributing data to the design curve. Increase in void ratio may result in a 10 - to 20 -percent increase in actual (as compared to predicted) shoaling volumes where sand accumulates in protected water. Void ratio should be measured in field studies of longshore transport. 
This report is published to show the relation between two versions of the energy flux method of predicting longshore transport: The volume rate prediction recommended in the Shore Protection Manual (SPM) (U.S. Army, Corps of Engineers, Coastal Engineering Research Center, 1977), and the immersed weight rate prediction proposed in other publications. The need for this explanation was indicated by inquiries from field engineers to the staff at CERC.

The report was prepared by Dr. Cyril Galvin, formerly Chief, Coastal Processes Branch, CERC, under the general supervision of Mr. R.P. Savage, Chief, Research Division.

Comments on this publication are invited.

Approved for publication in accordance with Public Law 166, 79th Congress, approved 21 July 1945, as supplemented by Public Law 172, 88th Congress, approved 7 November 1963.

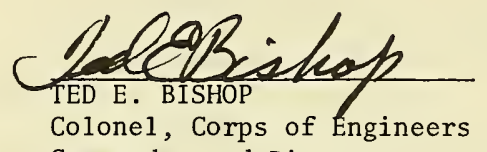

Commander and Director 


\section{CONTENTS}

Page

CONVERSION FACTORS, U.S. CUSTOMARY TO METRIC (SI) . . . . . . . 5

SYMBOLS AND DEFINITIONS. . . . . . . . . . . . . . . 6

I INTRODUCTION . . . . . . . . . . . . . . . . . . 7

1. Volume and Immersed Weight Rates of Longshore Transport. . . . . . . . . . . . . . . . . 7

2. Purpose . . . . . . . . . . . . . . . 8

I I UNIT WEIGHT OF SAND. . . . . . . . . . . . . . . . . . . 8

I I I PRESENT USE OF IMMERSED WEIGHT CALCULATION . . . . . . . . . . 10

IV RESULTS. . . . . . . . . . . . . . . . . . . 12

$\mathrm{V}$ CONCLUSIONS. . . . . . . . . . . . . . . . . . . . 12

LITERATURE CITED . . . . . . . . . . . . . . . . 15

TAB LE

Ranges of volume concentration, $a^{\prime}$, and unit weights of sand, $\gamma_{\text {. . . . . . . . . . . . . . . . . . . } 9}$

FIGURES

1 Two sets of longshore transport data from protected waters

related to SPM design curve . . . . . . . . . . . . . 11

2 Use of $I_{\ell}$ in present practice. . . . . . . . . . . . . 13 
U.S. customary units of measurement used in this report can be converted to metric (SI) units as follows:

\begin{tabular}{|c|c|c|}
\hline Multiply & by & To obtain \\
\hline $\begin{array}{l}\text { inches } \\
\text { square inches } \\
\text { cubic inches }\end{array}$ & $\begin{array}{l}25.4 \\
2.54 \\
6.452 \\
16.39\end{array}$ & $\begin{array}{l}\text { millimeters } \\
\text { centimeters } \\
\text { square centimeters } \\
\text { cubic centimeters }\end{array}$ \\
\hline $\begin{array}{l}\text { feet } \\
\text { square feet } \\
\text { cubic feet }\end{array}$ & $\begin{array}{l}30.48 \\
0.3048 \\
0.0929 \\
0.0283\end{array}$ & $\begin{array}{l}\text { centimeters } \\
\text { meters } \\
\text { square meters } \\
\text { cubic meters }\end{array}$ \\
\hline $\begin{array}{l}\text { yards } \\
\text { square yards } \\
\text { cubic yards }\end{array}$ & $\begin{array}{l}0.9144 \\
0.836 \\
0.7646\end{array}$ & $\begin{array}{l}\text { meters } \\
\text { square meters } \\
\text { cubic meters }\end{array}$ \\
\hline $\begin{array}{l}\text { miles } \\
\text { syuare miles }\end{array}$ & $\begin{array}{l}1.6093 \\
259.0\end{array}$ & $\begin{array}{r}\text { kilometers } \\
\text { hectares }\end{array}$ \\
\hline knots & 1.852 & kilometers per hour \\
\hline acres & 0.4047 & hectares \\
\hline foot-pounds & 1.3558 & newton meters \\
\hline millibars & $1.0197 \times 10^{-3}$ & kilograms per square centimeter \\
\hline ounces & 28.35 & grams \\
\hline pounds & $\begin{array}{l}453.6 \\
0.4536\end{array}$ & $\begin{array}{l}\text { grams } \\
\text { kilograms }\end{array}$ \\
\hline ton, long & 1.0160 & metric tons \\
\hline ton, short & 0.9072 & metric tons \\
\hline degrees (angle) & 0.01745 & radians \\
\hline Fahrenheit degrees & $5 / 9$ & Celsius degrees or Kelvins ${ }^{1}$ \\
\hline
\end{tabular}

${ }^{1}$ To obtain Celsius (C) temperature readings from Fahrenheit (F) readings, use formula: $C=(5 / 9)(F-32)$.

To obtain Kelvin (K) readings, use formula: $K=(5 / 9)(F-32)+273.15$. 
$a^{\prime}$ volume concentration, ratio of volume of solids to total volume in a sand deposit (defined by eq. 8), dimensionless

e void ratio, ratio of volume of voids to volume of solids in a sand deposit (defined by eq. 7), dimensionless

G specific gravity (defined by eq. 6), dimensionless

$I_{2}$ immersed weight rate of longshore transport (defined by eq. 5), pounds of sand (weighed under water) per year

$\mathrm{K}$ constant of proportionality in energy flux method (defined by eq. 1), cubic yards-seconds per pound-year

$P_{\text {ls }}$ the energy flux factor, foot-pounds per second per foot

Q volume rate of longshore transport, cubic yards per year

$\gamma$ unit weight of sand (defined by eq. 10), pounds per cubic foot

$\gamma_{s}$ unit weight of solids in sand, pounds per cubic foot

$\gamma_{s}^{\prime} \quad$ submerged unit weight of solids (defined by eq. 4), pounds per cubic foot

$\gamma_{w}$ unit weight of distilled water, pounds per cubic foot

$\gamma_{x}$ unit weight of water in which sand is immersed, pounds per cubic

NOTE.--The dimensionless immersed weight coefficient (Longuet and Higgins, 1972, p. 211), using the definitions above, equals the term in parenthesis in equation (5), multiplied by 2 to account for the use of significant height in $P_{\ell s}$, and divided by $31.536 \times 10^{6}$, the number of seconds in a year. 


\section{by \\ Cypil J. Galvin}

\section{INTRODUCTION}

1. Volume and Immersed Weight Rates of Longshore Transport.

Two general formulas are presently (1978) in use for predicting longshore transport rates from incident wave conditions. They are usually identified as the energy flux method and the immersed weight rate.

The energy flux method empirically relates longshore transport rate, $Q$, to a computed variable called the energy flux factor, $P_{\ell S}$, by an equation of the form:

$$
\mathrm{Q}=\mathrm{K} \mathrm{P}_{\mathrm{lS}} \text {. }
$$

The equation of this form recommended for design in the Shore Protection Manual (SPM) (U.S. Army, Corps of Engineers, Coastal Engineering Research Center, 1977) is

$$
Q=7,500 \mathrm{P}_{\ell S}
$$

where $Q$ is in cubic yards per year and $P_{l s}$ is in power per unit length of shore line (foot-pounds per second per foot). The proportionality constant, $K$, has units to balance the equation (cubic yardsseconds per pound-year).

A number of investigators recommend using the immersed weight rate of transport, $\mathrm{I}_{\ell}$, rather than Q (Bagnold, 1963; Komar and Inman, 1970; Longuet-Higgins, 1972). The immersed weight rate leads to a dimensionally homogeneous equation with a dimensionless coefficient, instead of the peculiar units that $K$ has in equation (1). The immersed weight is related to the volume rate by

$$
I_{\ell}=27 a^{\prime} r_{s}^{\prime} Q \text {. }
$$

where 27 converts cubic feet to cubic yards, $a^{\prime}$ is volume solids/volume sand in place, and $\gamma_{S}^{\prime}$ is the difference

$$
\gamma_{s}^{\prime}=\gamma_{s}-\gamma_{x}
$$

between specific weight of sand grain, $\gamma_{s}$, and water, $\gamma_{x}$; i.e., the immersed specific weight of the sand grain. From equation (1), the immersed weight longshore transport rate is

$$
I_{\ell}=\left(\begin{array}{llll}
27 & a^{\prime} & Y_{s}^{\prime} K
\end{array}\right) P_{\ell s} .
$$


Thus, the immersed rate is equal to flux rate multiplied by a term which is assumed to be constant.

\section{Purpose.}

There is some confusion concerning the relative validity of equations (2) and (5) as predictors of longshore transport. Authoritative publications have urged the use of $I_{\ell}$ in equation (5), and this has created the impression that the SPM equation (2) is distinct from, and inferior to, the immersed weight rate of computing longshore transport.

This report shows that, based on present knowledge, there is at this time (1978) no practical difference between equations (2) and (5). However, an immersed weight prediction could be important if significant variations in $a^{\prime}$ or $\gamma_{S}^{\prime}$ exist on the shore. This possibility suggests that measurements of $a^{{ }^{\prime}}$ and $\gamma_{s}^{\prime}$ should be included in field programs to measure longshore transport rate.

\section{UNIT WEIGHT OF SAND}

The applicability of an immersed weight transport prediction depends on a knowledge of the unit weight of sand. The discussion in this section concerns the unit weight of dry sand, but it is easily extended to cover sand immersed in seawater.

The unit weight of sand, $\gamma$, is dependent on two variables. The first variable is the specific gravity of the sand grains, given by

$$
G=\gamma_{S} / \gamma_{\omega}
$$

where $\gamma_{S}$ is the weight density of the material making up the sand grain, and $\gamma_{w}$ is the weight density of distilled water. Most sand grains are quartz with a specific gravity of 2.65 . However, on some beaches sand grains may be composed of calcium carbonate with a specific gravity, when a pure solid, from 2 to 11 percent higher than quartz (G of 2.71 for pure calcite to 2.94 for pure aragonite). (Carbonate sands may also be effectively lighter than quartz when grains are made of porous shell material.)

The second variable is the amount of space taken up by voids in the sand deposit. This can be described by several terms. The usual soil mechanics parameter is the void ratio, e, defined as

$$
\text { e = Volume of voids/volume of solids. }
$$


The usual parameter in coastal research (see eq. 3) is "volume concentration" defined as

$$
a^{\prime}=\text { Volume of solids/total volume. }
$$

The void ratio is related to the volume concentration by

$$
e=\left(1-a^{\prime}\right) / a^{\prime}
$$

In terms of the volume concentration, the unit weight of sand is

$$
\gamma=a^{\prime} G \gamma_{w} \text {. }
$$

The few times that the unit weight of sand has been considered in longshore transport predictions, it has been assumed that the sand is all quartz $(G=2.65)$ and that $a^{\prime}=0.60$. This value of $a^{\prime}$ is apparently derived from Chamberlain (1960) where $a^{\prime}=0.60$ is reported for fine sand collected from the beach face, after compaction. However, a'. can vary significantly. For example, Chamberlain reported data equivalent to $\mathrm{a}^{\prime}=0.53$ for sand at the head of a submarine canyon and as low as 0.27 for micaceous sand lower in the canyon (taken from Shepherd, 1963).

Theoretically, for sands consisting of perfect spheres of the same size, $a^{\prime}$ ranges from 0.52 to 0.74 , going from loosest to most dense (42 percent increase). The following Table shows the actual data (when converted to $a^{\prime}$ values) reported in Sowers and Sowers (1970, p. 30).

Table. Ranges of volume concentration, $a^{\prime}$, and unit weights of sand, $\gamma$ (from Sowers and Sowers, 1970).

\begin{tabular}{ccccc}
\hline Sand & $a^{\prime}{ }_{\max }$ & $\mathrm{a}^{\prime}{ }_{\min }$ & $\begin{array}{c}\gamma_{\max } \\
\left(1 \mathrm{~b} / \mathrm{ft}^{3}\right)\end{array}$ & $\begin{array}{c}\gamma_{\min } \\
\left(1 \mathrm{~b} / \mathrm{ft}^{3}\right)\end{array}$ \\
\hline $\begin{array}{c}\text { Uni form } \\
\text { subangular } \\
\begin{array}{c}\text { We11-graded } \\
\text { subangular }\end{array}\end{array}$ & 0.67 & 0.54 & 110 & 89 \\
\hline
\end{tabular}

Since $G$ and $a^{\prime}$ have been assumed to be 2.65 and 0.60 when calculated, this is equivalent to saying that all sand is assumed to have a unit weight, from equation (10), of 99.2 pounds per cubic foot.

Using the "relative density" as defined by Sowers and Sowers (1970, p. 31) and the Table, a sand having the assumed $a^{\prime}=0.60$ would be 
"loose" sand in the case of uniform well-rounded sand grains, slightly loose for uniform subangular sand, and the loosest possible for we11graded subangular sand.

However, it is probable that sand along the shoreline should be more on the dense side, rather than on the loose side because of the compacting effects of water soaking and wave action. Moreover, it is evident that the weight density will vary with the grain-size distribution and grain shape (Sowers and Sowers, 1970). Thus, the constant $a^{\prime}=0.60$ is an assumption not likely to be generally true.

Unit volume is equal to the reciprocal of the unit weight. Since uniform sands may vary 24 percent in unit weight (Table), the same variation may occur in unit volume. Since most independent, local field estimates of longshore transport are based on surveys of sand volumes, it is possible that the energy flux prediction can be significantly affected by variation in unit volume of the sand.

For example, Caldwell's (1956) and Komar's (1969) data are from surveys of the nearshore zone subject to wave action, and these data are 19 of the 23 data points used to establish the SPM longshore transport curve (Figure 4-37 in SPM). If the sand settled out in quieter waters, the same number of sand grains might be expected to yield larger surveyed volumes. This possibility is consistent with the data from Channel Islands Harbor (Bruno and Gable, 1977) and Santa Barbara (Galvin and Vitale, 1977), California, which do plot above the SPM curve (Fig. 1). (However, even a 24-percent decrease in unit volume would only bring these California data points about 20 percent closer to the SPM curve on that log-log plot.)

\section{PRESENT USE OF IMMERSED WEIGHT CALCULATION}

The immersed weight formulation has been strongly recommended by some for longshore transport prediction. As shown by equation (3), the immersed weight rate equals the volume rate multiplied by two sandrelated parameters, $a^{\prime}$ (eq. 8) and $\gamma_{S}^{\prime}$ (eq. 4).

However, the present use of $I_{\ell}$ with the SPM design curve (eq. 2) implies a constant unit weight which probably was lacking in the underlying data. The existing design curve in SPM is based on three sets of field data for which $a^{\prime}$ and even $\gamma_{S}^{\prime}$ are not available. One set measures short-term volume changes in the high tide surf zone (Komar, 1969); the second set measures longer term variations in the littoral zone (Caldwe11, 1956); and the third set measures pumping rates of probable carbonate sand (Watts, 1953). Thus, there is a good deal of uncertainty in $a^{\prime}$ and $\gamma_{s}^{\prime}$ for all three sets, and $a^{\prime}$ in particular is likely to be different in each set of data. Therefore, it is probable that all three sets of data involve slightly different unit weights of sand.

Those studies that use $I_{\ell}$ have assumed a $\gamma_{s}^{\prime}$ for quartz sand and $a^{\prime}=0.6$ to compute $I_{\ell}$. This is permissible when other data are lacking. 


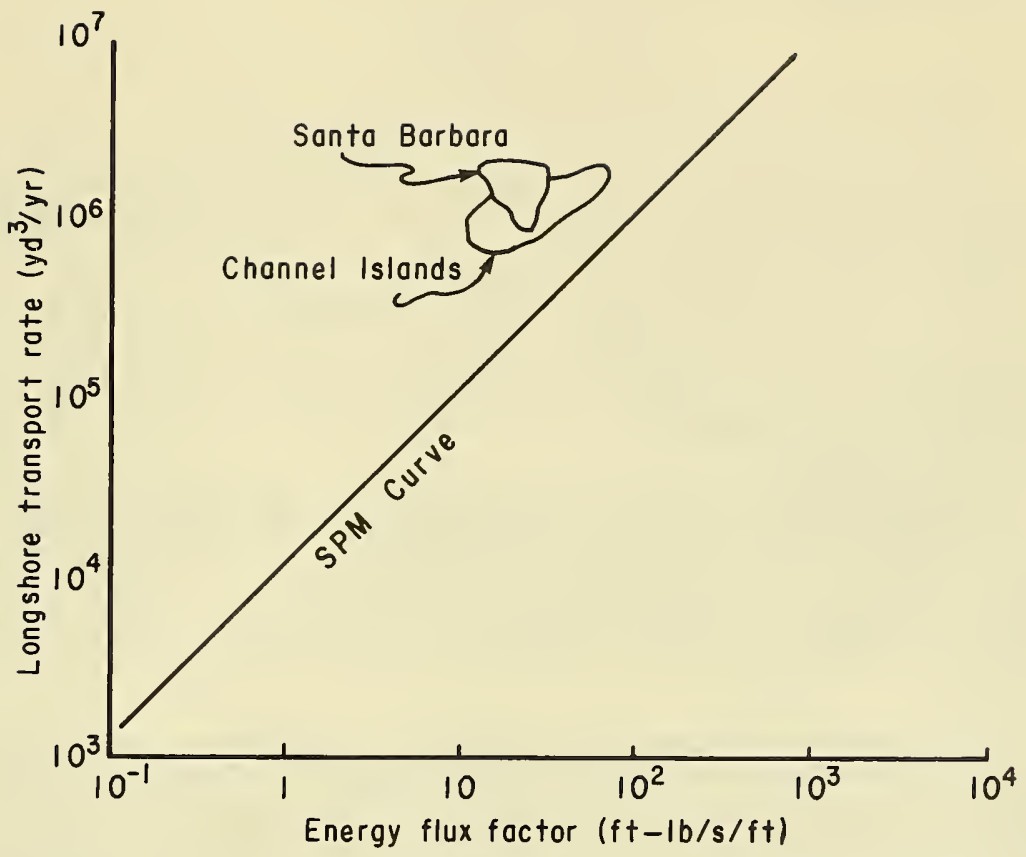

Figure 1. Two sets of longshore transport data from protected waters related to SPM design curve. 
However, to apply the result to typical engineering problems, the same assumptions must be made about $\gamma_{S}^{\prime}$ and $a^{\prime}$ to get back to a value of $Q$, since $Q$ is the quantity needed in design. The steps involved for the present immersed weight procedure are shown in Figure 2.

Although immersed weight rates are not presently practical in fieldwork, immersed weight rates of longshore transport are routinely measured in some laboratory experiments (Savage, 1959).

\section{RESULTS}

The results of this analysis are summarized as follows:

In practical application, the immersed weight formulation does not presently improve the engineering prediction. The required engineering quantity is a volume rate of sand in place, Q, and all the existing data were originally measured in terms of $Q$, or in $Q$ equivalents. Therefore, to develop the immersed weight formulation from existing data, it is necessary to estimate values of $a^{\prime}$ and $\gamma_{s}^{\prime}$ and convert $Q$ values to $I_{\ell}$ by equation (3). Then, to use the immersed weight formulation to solve a problem, the procedure must be reversed and converted back to the required $Q$.

Available data have led the investigators who have worked with $\mathrm{I}_{\ell}$ to assume that both $\mathrm{a}^{\prime}$ and $Y_{s}^{\prime}$ are constants. To the extent that this is a fact, $I_{\ell}$ is directly proportional to $Q$, independent of any other variables, and the use of $I_{\ell}$ is equivalent to $Q$, after two added calculations. However, in the three sets of data on which the SPM design curve is based, it is probable that neither a' or $\gamma_{S}^{\prime}$ were constant.

The available soil mechanics information indicates the need for more data on void ratio and sand grain specific gravity. The Table and related information suggest that $a^{\prime}$ may vary significantly, although the upper limit of variation is probably less than the theoretical 42-percent increase in $a^{\prime}$ possible in going from loosest to most dense packing of spherical sand grains. Most sand beaches are quartz, but calcium carbonate sands of the tropics could have a $\gamma_{s}^{\prime}$ (for pure aragonite) as much as 18 percent higher than quartz sands, or even less than quartz sands when the carbonate grains are derived from porous shell material.

\section{CONCLUSIONS}

1. Volume rate, $Q$, is the longshore transport parameter needed for design.

2. As presently used, the immersed weight rate equation is equal to the volume rate equation recommended by SPM, multiplied by a constant (eq. 3). Thus, the volume rate prediction (eq. 2) arrives more directly at $Q$. 


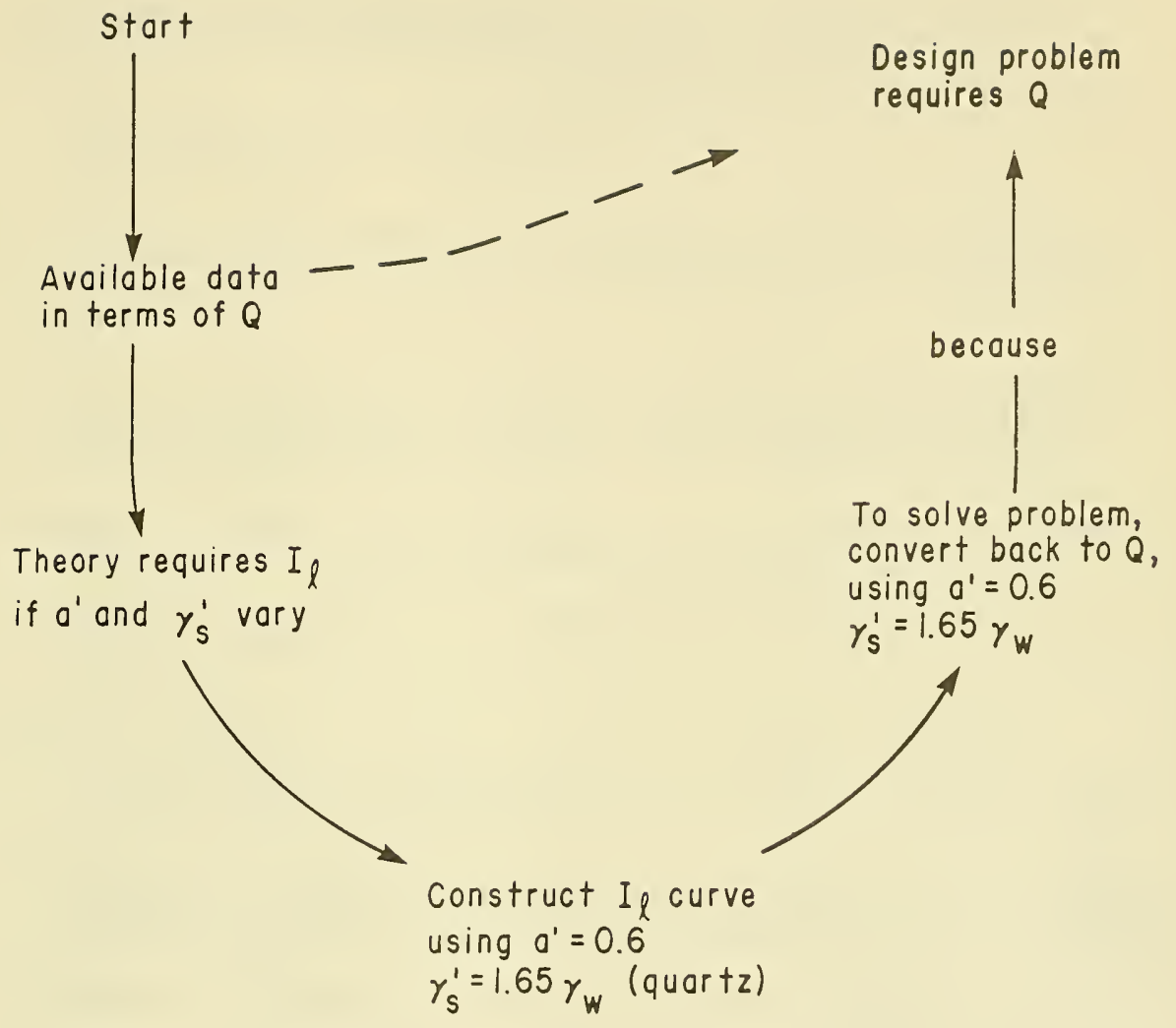

Figure 2. Use of $\mathrm{I} \%$ in present practice. 
3. Longshore transport which produces shoaling in protected waters could produce more shoaling than predicted merely because of looser packing of sand grains. The magnitude of this increase is expected to be on the order of 10 to 20 percent and should not be greater than 42 percent.

4. Field studies of longshore transport should include measurements to determine the void ratio (eq. 7), or equivalently a' (eq. 8), in the littoral zone and in protected waters. 
BAGNOLD, R.A., "Mechanics of Marine Sedimentation," The Sea, Vol. 3, John Wiley \& Sons, New York, 1963, pp. 507-528.

BRUNO, R.O., and GABLE, C.G., "Longshore Transport at a Total Littoral Barrier," Proceedings of the 15th Coastal Engineering Conference, American Society of Civil Engineers, Vol. 2, 1977, p. 1203.

CALDWELL, J.M., "Wave Action and Sand Movement Near Anaheim Bay, California," TM-68, U.S. Army, Corps of Engineers, Beach Erosion Board, Washington, D.C., Feb. 1956.

CHAMBERLIN, T.K., "Mechanics of Mass Sediment Transport in Scripps Submarine Canyon, California," unpublished $\mathrm{Ph} . \mathrm{D}$. Thesis, University of California, Scripps Institution of Oceanography, La Jolla, Calif., 1960 .

GALVIN, C., and VITALE, P., "Longshore Transport Prediction - SPM 1973 Equation," Proceedings of the 15th Coastal Engineering Conference, American Society of Civil Engineers, Vol. 2, 1977, pp. 1133-1148.

KOMAR, P.D., "The Longshore Transport of Sand on Beaches," unpublished Ph.D. Thesis, University of California, San Diego, Calif., 1969.

KOMAR, P.D., and INMAN, D.L., "Longshore Sand Transport on Beaches," Joumal of Geophysical Research, Vol. 75, No. 30, Oct. 1970, pp. 59145927.

LONGUET-HIGGINS, M.S., "Recent Progress in the Study of Longshore Currents," Waves on Beaches and Resulting Sediment Transport, Academic Press, New York, 1972, pp. 203-248.

SAVAGE, R.P., "Laboratory Study of Effect of Groins on Rate of Littoral Transport: Equipment Development and Initial Tests," TM-114, U.S. Army, Corps of Engineers, Beach Erosion Board, Washington D.C., June 1959.

SHEPARD, F.P., Submarine Geology, 2d ed., Harper and Row, New York, 1963.

SOWERS, G.B., and SOWERS, G.F., Introductory Soiz Mechanics and Foundation, 3d ed., The MacMillan Co., New York, 1970.

U.S. ARMY, CORPS OF ENGINEERS, COASTAL ENGINEERING RESEARCH CENTER, Shore Protection Manual, 3d ed., Vols. I, II, and III, Stock No. 00800113-1, U.S. Government Printing Office, Washington D.C., 1977, $1,262 \mathrm{pp}$.

WATTS, G.M. "A Study of Sand Movement at South Lake Worth Inlet, Florida," TM-42, U.S. Army, Corps of Engineers, Beach Erosion Board Washington, D.C., Oct. 1953. 



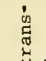

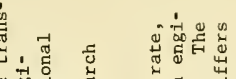

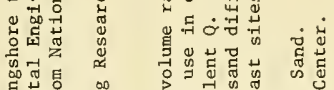

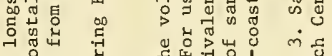

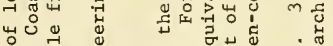

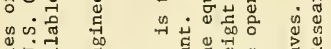

प्र

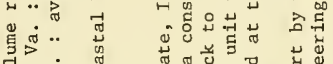

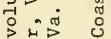

चैं

पू

क्ष.

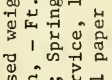

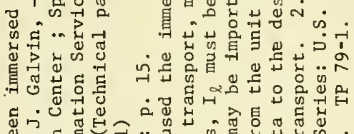

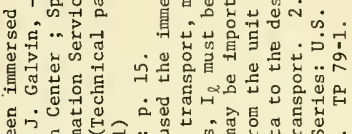

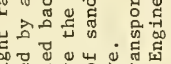

वे ज्ञ

ช

कै

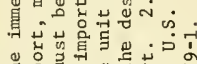

莺

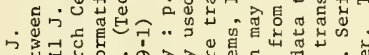

न

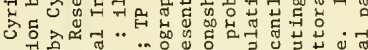

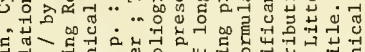

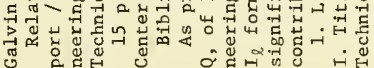

穿

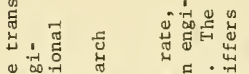

సิ

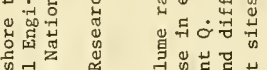

क्⿹

फ过

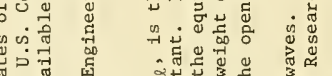

讨.. 留

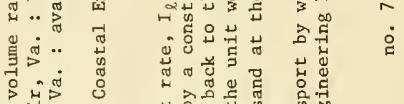

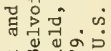

舟出余

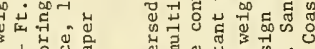

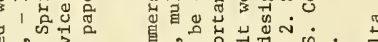

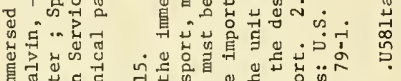

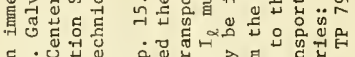

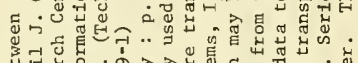

न

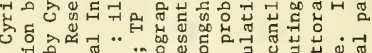

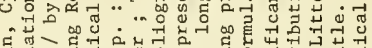

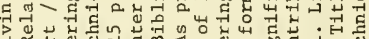

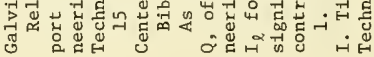

पु

पैत्ञ

品苟

品

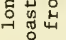

낭 吾

घं की त्र

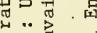

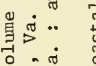

$\rightarrow \hat{H}>$

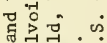

बैं एँ

舟出可

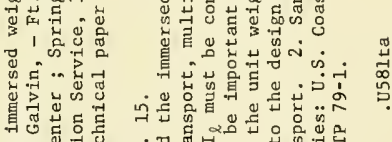

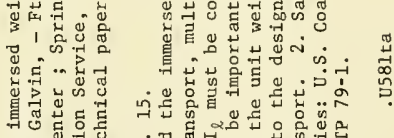

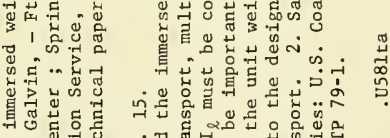

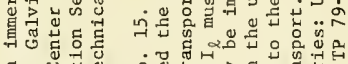

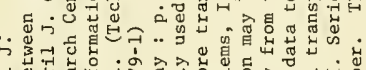

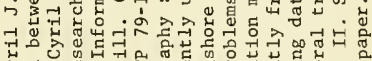

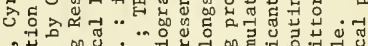

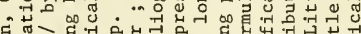

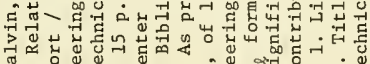

है 7 के

స్

芩, 元 ठ

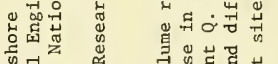

कृत

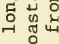

w

घु

荧...

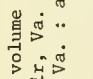

(

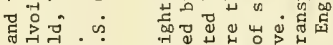

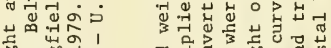

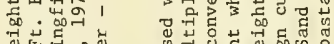

Ð

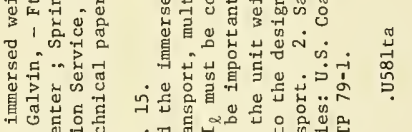

. 的范

न

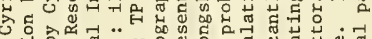

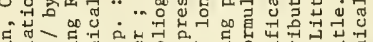

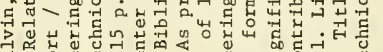





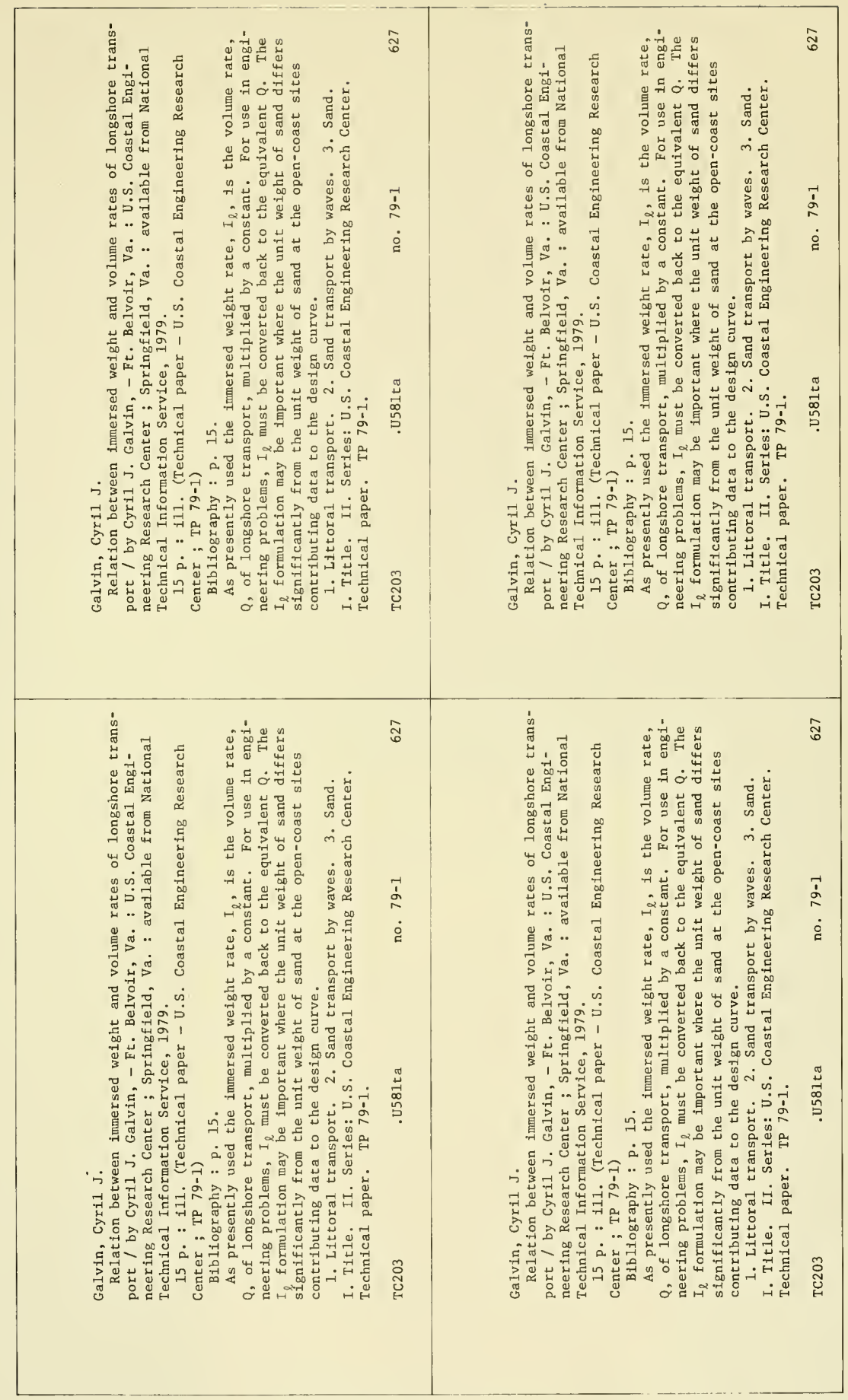




